\title{
Agent or principal? : A discursive and rhetorical approach to changing stakeholder relations in the entrepreneurial university
}

\section{Niska, Miira}

Edward Elgar

2021

Niska , M \& Vesala , K 2021, Agent or principal? A discursive and rhetorical approach to changing stakeholder relations in the entrepreneurial university . in U Hytti (ed.) , A Research agenda for entrepreneurial university . Edgar Research Agendas, Edward Elgar , Cheltenham , pp. 85-101 . https://doi.org/10.4337/9781788975049.00013

http://hdl.handle.net/10138/337171

https://doi.org/10.4337/9781788975049.00013

acceptedVersion

Downloaded from Helda, University of Helsinki institutional repository.

This is an electronic reprint of the original article.

This reprint may differ from the original in pagination and typographic detail.

Please cite the original version. 
Niska, M \& Vesala, K 2021, Agent or principal? A discursive and rhetorical approach to changing stakeholder relations in the entrepreneurial university. in U Hytti (ed.), A Research agenda for entrepreneurial university. Edgar Research Agendas, Edward Elgar, Cheltenham, pp. 85-101. https://doi.org/10.4337/9781788975049.00013

\section{$<$ b $>$ Introduction}

This is a draft chapter/article. The final version is available in A Research agenda for entrepreneurial university, published in 2021, Edward Elgar Publishing Ltd.

The entrepreneurial university is a fuzzy and an ambiguous concept. On the one hand, the concept suggests that the contemporary university is much like a business enterprise: effective, productive and profitable. On the other hand, the concept suggests that the university has "opened up" to the world outside and now engenders and supports business enterprises. The former meaning brings forth changes in funding and management, the latter meaning brings forth changes in external stakeholder relations. Whereas the "ivory tower" university focuses on academic interests in abstract and theoretical knowledge (Mautner, 2005; Nybom, 2008; Shore and McLauchlan, 2012), the entrepreneurial university fosters relationships with numerous external actors, including business sector actors, to promote social and economic development (Jongbloed et al., 2008; Philpott et al., 2011; OECD, 2012; Redford and Fayolle, 2014; Laalo and Plamper, 2019).

Transformation from the "ivory tower" to the entrepreneurial university requires changes in university-business sector relations. Before there can be spin-offs, there must be interaction and collaboration between the academic community and the business sector actors. Since this interaction and collaboration does not emerge automatically, universities have started to implement entrepreneurship policy. Interaction and collaboration with business sector actors can be facilitated, for example, with the help of start-up incubators, science parks and entrepreneurship education (Gilbert et al., 2004; Lundström and Stevenson, 2005; Audretsch and Beckmann, 2007). In this 
chapter, we argue that a crucial research agenda consists of understanding how new stakeholder relations are facilitated within the entrepreneurial university and how they work in practice.

Previous research constitutes a rich literature about university-business sector relations (Perkmann et al., 2013). Researchers have mainly used network analysis and stakeholder theory to map and classify these relations (Jongbloed et al., 2008; Perkmann et al., 2013; Redfrod and Fayolle, 2014), and explain their existence (Martinelli et al., 2008; D'Este and Perkmann, 2011; Perkmann et al., 2013). Although these studies have engendered important information, they have largely been based on substantialist (Emirbayer, 1997) and realist (Burr, 2015) assumptions. Researchers have been interested to explain university-business sector relations with multi-level factors like actors' motives and organizational cultures (i.e., substantialism). Researchers have based their studies on questionnaires filled in by academics, and these studies have been concerned with the reliability and validity of the research findings (i.e., realism) (see e.g., Perkmann et al. 2013).

We argue that in addition to substantialist and realist perspectives, it is also worthwhile to study stakeholder relations and their facilitation from relational (Emirbayer, 1997) and constructionist (Burr, 2015) perspectives. From a relational perspective, stakeholder relations are constructed and legitimated in situated and dynamic interaction processes. To understand relations with numerous partners and collaborators, it is best to study the everyday interactions in which these relations are constructed, managed and legitimated (i.e., using qualitative data). From a constructionist perspective, researchers cannot judge constructed relations in terms of their "truthfulness" simply because they have no access to the world "as it is". The relational-constructionist perspective allows us to study the context-specific construction of relations that take place in everyday interaction at the entrepreneurial university. Instead of truthfulness, it is intriguing to study how legitimate relationships are produced and why they are produced the way they are (Potter, 1996). 
In this chapter, we elaborate relational and constructionist perspectives with the help of discursive and rhetorical social psychology (Potter and Wetherell, 1987; Billig, 1996; Potter, 1996; Harré and van Langenhove, 1999). Discursive and rhetorical social psychology provide theoretically robust tools for the analysis of everyday interaction thorough which the entrepreneurial university's relations with partners and collaborators are constructed, authorized and legitimated - but also challenged and negotiated. The chapter is structured as follows. In section 2, we discuss the contribution of network analysis, stakeholder theory and agency theory to our understanding of relations at the entrepreneurial university. In section 3, we introduce a discursive and rhetorical approach to these relations. In section 4, we provide an empirical example and analysis of a speech of the rector of the University of Helsinki from discursive and rhetorical perspective. Finally, in the last section, we discuss our empirical example and the implications of our approach on the analysis of relations at the entrepreneurial university.

\section{<b> Relations at the entrepreneurial university: network analysis, stakeholder theory and agency theory}

Stakeholder theory, agency theory and related network analysis are all widely known in entrepreneurship and management studies (Aldrich and Zimmer, 1986; Ross, 1973; Mitchell et al., 1997; Alsos et al., 2011). They have also been applied in the higher education context to analyse universities' relationships to people, groups, organisations and institutions (Jongbloed et al., 2008; Martinelli et al., 2008; Siegel and Wright, 2015). Stakeholder theory focuses specifically on actors who have legitimate interests in a university's actions (Donaldson and Preston, 1995; Mitchell et al., 1997). The "ivory tower" universities acknowledge and serve internal, academic actors' interests in public knowledge promotion, excellence in teaching and research, respectable reputation 
and autonomy of knowledge (Mautner, 2005; Nybom, 2008; Shore and McLauchlan, 2012). The entrepreneurial universities, in turn, are also responsive to external non-academic actors' interests, and satisfy societal and market demands through knowledge transfer and academic entrepreneurship (Jongbloed et al., 2008; Philpott et al., 2011; Shore and McLauchlan, 2012).

A widely recognised problem at the entrepreneurial university is the academic community students and faculty members -, which does not always recognise the legitimacy of the new stakeholders. Previous research has demonstrated how the academic community impugns universities' collaboration with business sector on the basis that commercial interests violate "pure academic values" or "traditional ethos" (Lee, 1996; Ylijoki, 2003; Philpott et al., 2011). According to Jongbloed et al. (2008: 317), faculty members define "their identity as characterized by an independence of thought and action and do not want to be driven by external demands". Unwillingness to serve the interests of the new external stakeholders highlights the fundamental difference between universities and enterprises. Employees of a company may not be allowed to act against the business owners' will (at least without being fired) but students and faculty members are not employees of a single company called University. Instead of a principal with unambiguous interests, universities consist of separate disciplines and departments. The existence of distinct cultures, values and interests between the disciplines and departments has been something of a truism (e.g., Rinne, 2019). Not all members of the academic community have traditionally been willing to serve the same principals and interests.

Siegel and Wright (2015) discuss problems with stakeholder relations referring to the agency theory (Ross, 1973; Kiser, 1999; Shapiro, 2005). Agency theory focuses on relationships in which one party is designated as the principal, and the other party is designated as the agent who serves the principal. In the classic version, the business owner is the principal and the paid manager is the 
agent. The classic agency problem arises when the principal suspects that the agent is serving his/her own interests instead of maximising the interests of the principal (Jensen and Meckling, 1976). At the entrepreneurial university, the classic agency problem arises when business sector actors as stakeholders or principals suspect that faculty members (agents) collaborate with them in order to support their own academic research - not to transfer their knowledge to benefit the business (e.g., D’Este and Perkmann 2011).

The original formulation of agency theory assumes that there is just one principal, whose interests the agent serves. However, as Siegel and Wright (2015) demonstrate, stakeholder relations may face problems because agents have multiple principals whose interests they need to serve. For example, technology transfer offices (TTOs) must serve the interests of their clients (i.e., academic entrepreneurs) and the interests of the universities who established the TTOs (Siegel and Wright, 2015). In such situations, agents need to figure out how to deal with multiple principals and their interests.

An interesting detail in Siegel and Wright's (2015) example is the fact that the entrepreneurial university is portrayed as the principal, not the agent. Researchers often take for granted that the entrepreneurial university is the agent who serves the interests of external stakeholders (e.g., Redford and Fayolle, 2014). The concept "third mission" highlights universities' responsiveness to new partners (Jongbloed et al., 2008) in the sense that universities are agents who serve new partners' interests - not in the sense that new partners become agents who serve universities' academic interests.

Despite the "third mission", the entrepreneurial university is not only an agent for external principals. It is also a principal who authorises agents to act on its behalf (see Meyer and Jepperson, 
2000). For example, Laalo and Plamper (2019: 444) demonstrate how academic managers construct students and faculty members as effective agents for the entrepreneurial university. Unlike the assumption in the classic formulation of agency theory, agent and principal are not fixed positions. As Shapiro (2005: 267) notes: "actors are not just principals or agents, but often both at the same time - even in the same transaction or hierarchical structure". We argue that this complexity, or ambiguity, in stakeholder relations should be taken into consideration and relational-constructionist discursive and rhetorical social psychology provide theoretically robust tools for such research.

\section{$<$ b $>$ Discursive and rhetorical approach on stakeholder relations}

Discursive approaches are widely used in entrepreneurship and management studies (Hjort and Steyaert, 2004; Perren and Jennings, 2005; Anderson and Warren, 2011). In the higher education context, researchers have mainly adopted Foucauldian and critical discourse analysis to study, for example, universities' websites, job advertisements and rectors' speeches (Fairclough, 1993; Mautner, 2005; Krejsler, 2006). In these studies, researchers have taken a critical stand on the development of the entrepreneurial university. They have demonstrated how industrial and commercial ideas have penetrated and colonised universities, and they have argued for universities' emancipation from the hegemonic entrepreneurship discourse (e.g., Mautner, 2005). Research that focuses on power and subjugation at the entrepreneurial universities could be labelled as representing macro social constructionism (Burr, 2015) and radical or critical entrepreneurship research (Grant and Perren, 2002; see also Jennings, Perren and Carter, 2005; Berglund and Verduijn, 2018).

The discursive approach we adopt, discursive and rhetorical social psychology (Potter and Wetherell, 1987; Billig, 1996; Potter, 1996; Harré and van Langenhove, 1999), could be labelled as 
representing micro social constructionism (Burr, 2015) and interpretive entrepreneurship research (Grant and Perren, 2002; see also Jennings et al., 2005). Instead of focusing on the macro level linguistic structures (i.e., the entrepreneurship discourse or the managerial discourse) that frame actions at the entrepreneurial university, discursive and rhetorical social psychology focus on language use in everyday interaction. The purpose is to understand the construction of phenomena such as interests or agent-principal relations at the entrepreneurial university. In line with Burr (2015: 17), these "phenomena become things we do rather than things we have". The purpose is not to take a stand on the overall goodness or badness of the entrepreneurship discourse or development of the entrepreneurial university.

From discursive and rhetorical perspectives, stakeholders and agents who serve these stakeholders are constructed and legitimated in daily interaction processes. This construction and legitimation takes place, for example, in the interaction processes of positioning (Harré and van Langenhove, 1999), and stake and accountability management (Potter, 1996). Researchers have demonstrated how actors construct themselves as principals of numerous agents (e.g., Niska and Vesala, 2013), and agents for numerous principals (e.g., Jarzabkowski and Sillince, 2007).

From the discursive and rhetorical perspective, stakeholders' attributes - including their power and legitimacy (Mitchell et al., 1997) - are effects of discourse and thus negotiated in daily interactions. The same way agents' attributes - including their ability and willingness to serve the stakeholders are negotiable. This constructed nature means that legitimate positions of agent and principal can also be called into question, challenged or even rejected (Niska and Vesala, 2013). The discursive and rhetorical perspective engenders new research questions. How do actors construct themselves as legitimate stakeholders (i.e., principals) of the entrepreneurial university? How do actors construct the entrepreneurial university as an efficient agent for the legitimate stakeholders (i.e., 
principals)? How do actors construct the entrepreneurial university as a legitimate principal and authorise actors to serve its interests?

\section{<b> Empirical excursion: authorizing agents to engage in relations with business sector actors}

As a demonstration of discursive and rhetorical approach on stakeholder relations, we analysed a case of entrepreneurship policy implementation at an entrepreneurial university. The case is a speech given by Jukka Kola, the rector of the University of Helsinki (2013-2018) ${ }^{1}$. This speech is an opening speech in an event called How to Change the World (Miten maailmaa muutetaan, in Finnish). The event was organised by the central campus Helsinki Think Company. The central campus Helsinki Think Company, established in 2013, is a body that hosts and promotes entrepreneurship for the faculties of Arts, Educational Sciences, Law, Social Sciences and Theology (see also Chapter 5: Orchestrating affect at the entrepreneurial university).

The purpose of this event was to promote entrepreneurship with the help of inspirational speeches from experts like Bruce Oreck, an American diplomat and entrepreneur (Helsinki Think Company, 2016). Inspirational speeches from inspirational people are a widespread practice in entrepreneurship promotion in university contexts (see also Chapter 5: Orchestrating affect at the entrepreneurial university). The event took place in the 700-seat Great Hall of the university main building on 22 September 2016 and it clearly targeted the university community members, especially students and staff members. Representatives of the Helsinki Think Company hosted the event and the Great Hall was crowded. The event was recorded and it is available in YouTube: https://www.youtube.com/watch?v=h6UU8NMzAS8 (accessed 13 November 2019. Note: it is

\footnotetext{
${ }^{1}$ After working at the University of Helsinki, Kola was appointed as the rector of the University of Turku (2019-).
} 
mainly in Finnish, translated by the second author. The rector's speech starts at 5.15). We have given punctuation and added some capital letters to the transcription for ease of reading (see e.g., Reynolds et al., 2007).

Previous research has demonstrated that compared to other faculties, the attitudes to entrepreneurship are especially negative in faculties of Arts, Social and Behavioural Sciences (e.g., Philpott et al., 2011; Neittaanmäki et al., 2017). The rector of the University of Helsinki was thus opening an event to promote entrepreneurship to an audience known to be critical of entrepreneurship. From discursive and rhetorical perspectives, an interesting question is what is the rector doing in this situation? How is he constructing and legitimating (a) entrepreneurship and (b) relations between the university and stakeholders?

The speech of the rector (recorded 22 September 2016).

1 Good afternoon ((pushes his ear towards audience)). Well yes, interactivity, please, 2 that is what we need also this evening right here. Quite splendid to see so many of you 3 here. I guess it was a small surprise that the hall is so crowded in this kind of event 4 but that's how it should be. Now we are close to very essential issues what we are going 5 to do and what we have already done in this university. This, how to change the world and 6 it starts actually if we have the desire to change it, which takes us into the question that if 7 we have the desire, so do we have the ability to change that world. And as a matter of fact, 8 now a little bureaucratic mention, in the university law it is stated very clearly that the 9 mission of universities is to educate youth to serve the fatherland and humankind. And now 10 many of you who are people from the University of Helsinki know that I have said this so 11 many times, but it is not enough, at least for the University of Helsinki. We educate youth, 12 our young students, and also more experienced students, we educate youth to change the 13 world into a better place to live in, for everybody in this country and in the world. And it 14 takes lots more than just to serve and adjust oneself. Changing is the driving force, it is the 15 factor into which we invest in our training. And that training is based on top research 16 through which our students always have available the latest knowledge, even earlier than 17 many others who don't even know about it because our teachers deliver it there and because 18 they are researchers as well. In this way that special expertise is built, that special know19 how, and that special desire and ability to change the world into a better place to live. Our

20 Think Company, these young people here, and many others have acted before, are in 21 particular an example of how we involve our youth early enough in these activities. And it 
22 is in particular these youngsters who make the future. And when they also look at it from

23 the perspective of this kind of enterprise, entrepreneurship, creating new. One of our ideas

24 was exactly that the first Think Company came into the central campus in particular, where

25 perhaps there was not necessarily the readiness to see these things. And now we have gone

26 already to the Viikki campus, Meilahti campus and Kumpula campus is coming as well. In

27 other words, each of our four campuses will have a Think Company. A system driven by

28 students, pushed by students, and of student origin, with the help of which we do this thing

29 and through which we make the world a better place. Based on research but those ideas can

30 be such that there is also something that has not been researched yet. Young people have

31 some new, and often even many new thoughts. And as a matter of fact as a university rector

32 this is a special workplace you could say when working at the university not only as rector,

33 when every year new people come in. Also this year, a couple of weeks ago, about four

34 thousand new students came into this community, all at once just like that. Think about how

35 much that changes that community within a blink of an eye. Many new ideas thoughts

36 coming in. And they will be tested and then one starts to consider how things are taken

37 forward. It happens through the young people. Universities are forerunners, leading the

38 way. But in particular in that way that we have those young people here. It can be that us

39 older people will get stuck every now and then but those young people spar with us. They

40 make us think that where are we heading actually. In other words Think Company is such a

41 thing that is very important to us. Its impact starts to be pretty much what is should be but

42 one can build much more of it. Let's give one example, this morning there was Helsinki

43 innovation aquarium there at Luomus, the natural science central museum. And there were

44 many investors who also read, read and watch what kind of new moves come through our

45 science based ideas into business world, start-ups, spin-offs and so on. So this supports all

46 that young ones, utilize thoughts, be brave, take forward, change the world, that is one of

47 the main tasks of University of Helsinki. To change the world into a better place to live,

48 thanks so much.

The rector begins his speech with a greeting "good afternoon" and invites the audience to reply by pushing his ear forward (line 1). He thanks the audience for attending the event: "quite splendid to see so many of you in here" (lines 2-3). This acknowledgement is followed by an interesting remark: "I guess it was a small surprise that the hall is so crowded in this kind of event" (line 3).

What does the rector mean with "this kind of an event" and why is it surprising that the event turned out to be popular? One reasonable interpretation is that the rector implies that previously the university community at the central campus has not been that interested in entrepreneurship or inspirational speeches given by entrepreneurs (see Chapter 5: Orchestrating affect at the entrepreneurial university). 
The rector continues by stating that the popularity of the event is a good thing because changing the world is an essential part of what the University of Helsinki does (lines 4-7). One might of course wonder why the university institution is aiming to change the world - should not the institution focus on academic education and research. The rector legitimises the world-changing mission by referring to the Universities Act: "in the university law it is stated very clearly that the mission of the university is to educate the youth to serve the fatherland and humankind" (lines 8-9). The rector thus refers to the Universities Act to point out that the University of Helsinki is acting as an agent for two legitimate principals: Finland and humankind.

The construction of the two stakeholders, Finland and humankind, includes an interesting particular. On lines 9-13, the rector positions himself as an authority, who interprets critically the Universities Act, who can redefine the mission of the University of Helsinki. According to the rector, the University of Helsinki does not educate students to serve Finland and humankind by adjusting themselves but instead by changing Finland and the world for better (lines 8-14). Thus, besides arguing that the university serves two legitimate principals, the rector also actively defines how the university and its students should serve these principals. While highlighting change agency as the university's mission, the rector also highlights his own position as a person with authority to define the mission of the university and thereby manage or interpret the interests of the principals.

The rector also connects education and research (first and second missions) to the world-changing mission. According to the rector, research forms the basis of university education and the university education forms the basis of the world-changing action (lines 14-18). Following this interpretation, the third mission is really the main mission of the university; in the end, academic research and teaching inevitably also serve the interests of Finland and humankind. 
From education and research, the rector moves into talking about the Helsinki Think Company and students who take part in Helsinki Think Company activities. He presents these two as an example of "how we involve our youth early enough in these activities" (line 21). One might ask, who are "we" and what are "these activities" in the rector's account. One reasonable interpretation is that according to the rector, the University of Helsinki involves its students at an early stage into serving the legitimate stakeholders as change-agents. The rector thus positions the Helsinki Think Company and students as agents for external principals.

The term entrepreneurship is first used when the rector continues that students "make the future and when they look at it also from the perspective of this kind of enterprise, entrepreneurship, creating new" (lines 22-23). He invokes entrepreneurship not only as something that has to do with business enterprises but also as a vehicle of change - a construction familiar from Schumpeterian entrepreneurship theories and discourses. In this sense, entrepreneurship appears as a desirable way to serve the legitimate stakeholders. The rector adds that the Helsinki Think Company was established on the central campus of the University of Helsinki because the faculties located on the central campus did not necessarily have "the readiness to see these things" (line 25). One reasonable interpretation of this argument is that according to the rector, the Helsinki Think Company was needed because the academic community at the central campus struggled to see entrepreneurship as a vehicle through which they could serve Finland and humankind.

The rector makes an effort to pinpoint that the Helsinki Think Company is not a top-down institution but a bottom-up institution run by the students: "Think Company, a system driven by students, pushed by students, and of student origin" (lines 27-28). This is an interesting claim considering that previous studies have highlighted the role of the university administration in the 
establishment of the Helsinki Think Company (e.g., Siitonen, 2016). Nevertheless, the argument supports at least two impressions. Firstly, the Helsinki Think Company and its students are portrayed as dynamic agents. Even if their ideas are based on academic research (line 29), they still represent young people who are not "stuck" (lines 29-39). Presumably, the "stuck ones" here refer to the faculty members. Secondly, the Helsinki Think Company is portrayed as an agent serving students' interests - not only university politics or external actors' interests. The portrayal of the Helsinki Think Company as a bottom-up institution aligns students' interests with the interests of the external stakeholders.

The final part of the rector's speech starts with an affirmation of the importance of the Helsinki Think Company: "In other words Think Company is such a thing that is very important to us" (lines 40-41). One might ask who "we" are in this account. The rector might refer to the University of Helsinki, to the Finns, or to humankind. Although the rector expresses that he is pleased with the impact of the Helsinki Think Company (line 41), he also envisions a future in which the impact is even higher. Assessments like these obviously construct the rector as a representative of a principal who is monitoring the agent.

As an example of wanted future actions, the rector narrates another event he had participated that morning. In this event, investors considered making investments in science-based ideas that came from the University of Helsinki (lines 42-45). Here the rector adopts the discourse commonly known as the entrepreneurship discourse and talks about start-ups and spin-offs (line 45). He also introduces a new stakeholder: investors who are interested in science-based ideas (line 44). Here, entrepreneurship is associated with business enterprises and dynamic business activities. Again, the rector appears as a representative of a principal who outlines the expected direction of the agent's activities. 
The end of the speech is almost like the great commission: "utilize thoughts, be brave, take forward, change the world, that is one of the main tasks of the University of Helsinki. To change the world into a better place to live" (lines 46-47). This encouragement illustrates well the overall nature of the rector's speech. The rector is authorizing students and the Helsinki Think Company to act as agents who will seek to change the world for better, create contacts with and cooperate with the business sector, in the name of University of Helsinki, Finland, and humankind.

The answer to the questions about how the rector of the University of Helsinki is constructing and legitimating entrepreneurship, and relationships between the university and the stakeholders, is tripartite. Firstly, the rector constructs the University of Helsinki as an agent that serves two main stakeholders: Finland and humankind. According to him, the Universities Act legitimates these stakeholders, yet he reinterprets the mission stated in the Act. Furthermore, a third legitimate stakeholder - investors - comes up when the rector adopts the entrepreneurship discourse. Secondly, in line with the third mission discussions, the rector constructs entrepreneurship as a vehicle of change through which the University of Helsinki can serve the external stakeholders: Finland and humankind, but also investors and the business sector. Thirdly, besides an agent for external principals, the rector constructs the University of Helsinki a principal that authorises the Helsinki Think Company and the academic community as agents for not three but four principals. The rector implies that students' interests align with the stakeholders' interests but faculty members are a reluctant group, which - unlike students - "has not seen the light". The speech ends with the rector authorising the Helsinki Think Company and the audience to act as agents for Finland, humankind, the business sector - and the University of Helsinki.

\section{<b > Discussion and conclusions: ways to move forward}


New stakeholder relations are an important feature of the entrepreneurial university. In this chapter, we have emphasised that these relations and their facilitation and legitimation can be viewed from relational-constructionist perspective as dynamic and situationally negotiated. While we acknowledge that discursive and rhetorical social psychology are not the only possible approaches, they provide theoretically robust tools for the analysis of everyday interaction in which the relations between the academic community and external stakeholders are constructed and legitimated.

Based on discursive and rhetorical perspective, we argue that a crucial research agenda consists of understanding (a) how entrepreneurship is constructed and (b) how these constructions facilitate or impair stakeholder relations at the entrepreneurial university. Hytti et al. (2017) call for a more refined understanding of local interpretations of entrepreneurship. Discursive and rhetorical social psychology are oriented to situationally constructed interpretations but also note that these interpretations are constructed to do things like facilitate - or impair - relationship building (Potter and Wetherell, 1987; Billig, 1996; Potter 1996).

In the empirical example, we analysed a speech made by the rector of the University of Helsinki, in which he constructed entrepreneurship in two distinct ways. Firstly, the rector constructed entrepreneurship as "more than business making". Entrepreneurship equals heroic action that changes the world for better. This image of an entrepreneur as a saviour has also been identified in other contexts (e.g., Sørensen, 2008). Secondly, the rector constructed entrepreneurship as dynamic business making that is manifested in spin-offs and start-ups, which attract investors. The speech demonstrates that entrepreneurship is a fuzzy and ambiguous concept. It is by no means self-evident how entrepreneurship is interpreted in the local contexts of the entrepreneurial university. 
The speech is an example of entrepreneurship policy implementation; in the speech, the rector activated and authorised students and faculty members to relate to the business sector and become entrepreneurial agents for the legitimate stakeholders: Finland, humankind, investors and the University of Helsinki. Public speeches represent a specific type of formal and unidirectional interaction, which does not allow for disagreements. Analysis of a public speech cannot revel how the audience, academic community members, reacted to the rectors' constructions. However, the entrepreneurial university is also filled with informal and bidirectional communication through which entrepreneurship and relations between academic community members and external stakeholders are constructed but also challenged and negotiated. These interaction situations, such as consultation and counselling situations and advisory board meetings, make an interesting context for empirical research.

Considering that disciplines and departments have not traditionally shared cultures, values or interests (e.g., Rinne, 2019), it is important to study the construction of entrepreneurship and stakeholder relations in local contexts. In the speech, for example, the rector acknowledges the unwillingness of some academic community members to embrace entrepreneurship and business sector relations. Opposition to the entrepreneurial university has mainly been studied from Foucauldian and macro constructionist perspectives (e.g., Fairclough, 1993; Mautner, 2005; Krejsler, 2006). We argue that researchers should also take a discursive and rhetorical perspective on the counter talk, in which constructions of entrepreneurship are used to challenge new stakeholder relations.

Michael Billig (1996), a key author in discursive and rhetorical social psychology, has reflected on the transition from the "ivory tower" to the entrepreneurial university. According to Billig (1996), a major change in the university contexts is that funding is no longer sought in order to do research, 
but research is done in order to get funding. Economic interests no longer serve academic interests but academic interests serve economic interests. We argue that an important research agenda consists of studying who serves whom in the local contexts of the entrepreneurial university.

\section{$<$ b $>$ References}

Aldrich, H. \& Zimmer, C. (1986). Entrepreneurship through social networks. In: D.L. Sexton \& R.W. Smilor (eds.), The Art and Science of Entrepreneurship. Cambridge: Ballinger.

Alsos, A. G., Hytti, U \& Ljunggren, E. (2011). Stakeholder Theory Approach to Technology Incubators. International Journal of Entrepreneurial Behaviour \& Research, 17 (6), 607-625.

Anderson, A. R. \& Warren, L. (2011). The entrepreneur as hero and jester: Enacting the entrepreneurial discourse. International Small Business Journal, 29 (6), 589-609.

Audretsch, D.B. \& Beckmann, I.A.M. (2007). From small business to entrepreneurship policy. In D.B. Audretsch, I. Grilo \& A.R. Thurik (eds.), Handbook of Research on Entrepreneurship Policy (pp.36-53). Cheltenham: Edward Elgar.

Berglund, K. \& Verduijn, K. (2018). Introduction: Challenges for entrepreneurship education. In: K. Berglund \& K. Verduijn (eds.), Revitalizing Entrepreneurship Education. Adopting a critical approach in the classroom. London: Routledge.

Billig, M. (1996). Arguing and Thinking (2 ${ }^{\text {nd }}$ ed.). Cambridge: Cambridge University Press.

Burr, V. (2015). Social Constructionism ( $3^{\text {rd }}$ ed.). London: Routledge.

D’Este, P. \& Perkmann, M. (2011). Why do academics engage with industry? The entrepreneurial university and individual motivations. Journal of Technology Transfer, 36, 316-339. 
Donaldson, T. \& Preston, L.E. (1995). The Stakeholder Theory of the Corporation: Concepts, Evidence, and Implications. The Academy of Management Review, 20 (1), 65-91.

Emirbayer, M. (1997). Manifesto for a Relational Sociology. American Journal of Sociology, 103 (2), 281-317.

Fairclough, N. (1993). Critical discourse analysis and the marketization of public discourse: the universities. Discourse \& Society, 4 (2), 133-168.

Gilbert, B.A., Audretsch, D.B. \& McDougall, P.P. (2004). The emergence of entrepreneurship policy. Small Business Economics, 22 (3-4), 313-323.

Grant, P. \& Perren, L. (2002). Small Business and Entrepreneurial Research. Meta-theories, Paradigms and Prejudices. International Small Business Journal, 20 (2), 185-211.

Harré, R. \& van Langenhove, L. (eds.) (1999). Positioning Theory. Oxford: Blackwell.

Helsinki Think Company (2016). Miten maailmaa muutetaan. Facebook event. Available: https://www.facebook.com/events/helsingin-yliopiston-p\%C3\%A4\%C3\%A4rakennusaleksanterinkatu-5/miten-maailmaa-muutetaan/919755894817610/(accessed 26 March 2019) Hjort, D. \& Steyaert, C. (eds.) (2004). Narrative and Discursive Approaches in Entrepreneurship. A Second Movements in Entrepreneurship Book. Cheltenham: Edward Elgar.

Hytti, U., Eriksson, P., Montonen, T. \& Peura, K. (2017). Making sense of entrepreneurship at the universities - absolutely fabulous? Paper at the RENT Conference in Lund, Sweden, 16-17 November 2017. Available: https://research.utu.fi/converis/portal/Publication/27688756?lang=fi FI (accessed 26 March 2019)

Jarzankowski, P. \& Sillince, J. (2007). A Rhetoric-in-Context Approach to Building Commitment to Multiple Strategoc Goals. Organization Studies, 28 (11): 1639-1665. 
Jennings, P., Perren, L. \& Carter, S. (2005). Alternative Perspectives on Entrepreneurship Research. Entrepreneurship Theory \& Practice, 29 (2), 145-152.

Jensen, M.C. \& Mecklin, W.H. (1976). Theory of the Firm: Managerial behavior, agency costs and ownership structure. Journal of Financial Economics, 3 (4), 303-360.

Jongbloed, B., Enders, J. \& Salerno, C. (2008). Higher education and its communities: Interconnections, interdependencies and a research agenda. Higher Education, 56 (3): 303 - 324.

Kiser, E. (1999). Comparing Varieties of Agency Theory in Economics, Political Science, and Sociology: An Illustration from State Policy Implementation. Sociological Theory, 17 (2), 146-170.

Krejsler, J. (2006). Discursive Battles about the Meaning of University: the case of Danish university reform and its academics. European Educational Research Journal, 5 (3-4), 210 - 220.

Laalo, H. \& Plamper, R. (2019). Rehtorit managereina - Yritysyliopistoparadigma ja managerialistinen hallintatapa lukuvuoden avajaispuheissa. In H. Nori, H. Laalo \& R. Rinne (eds.), Kohti oppimisyhteiskuntaa - Koulutuspolitiikan uusi suunta ja korkeakoulutuksen muuttuva maisema (pp. 425-450). Turun yliopiston kasvatustieteiden tiedekunnan julkaisuja A:217. Turun yliopisto.

Lee, Y.S. (1996). Technology transfer' and the research university: a search for the boundaries of university-industry collaboration. Research Policy, 25, 843-863.

Lundström, A. \& Stevenson, L.A. (2005). Entrepreneurship Policy. Theory and Practice. International Studies in Entrepreneurship. New York: Springer.

Martinelli, A., Meyer, M. \& von Tunzelmann, N. (2008). Becoming an entrepreneurial university? A case study of knowledge exchange relationships and faculty attitudes in a medium-sized, research-oriented university. Journal of Technology Transfer, 33, 259-283. 
Mautner, G. (2005). The Entrepreneurial University: A discursive profile of a higher education buzzword, Critical Discourse Studies, 2 (2), 95-120.

Meyer, J.W. \& Jepperson, R.L. (2000). The ‘Actors’ of Modern Society: The Cultural Construction of Social Agency. Sociological Theory, 18 (1), 100-120.

Mitchell, R. K., Agle, B.R. \& Wood, D. J. (1997). Towards a theory of stakeholder identification and salience: defining the principle of who and what really counts. Academy of Management Review, 22 (4), 853-886.

Neittaanmäki, P., Mononen, L. \& Kinnunen, P. (2017). Innovaatiot ja yrittäjyys osana yliopistoopintoja (Innovations and entrepreneurship as part of university studies). Available at: https://www.jyu.fi/it/tutkimus/infjulk36 (accessed 26 June 2017).

Niska, M. \& Vesala, K.M. (2013). SME policy implementation as a relational challenge. Entrepreneurship \& Regional Development, 25 (5-6), 521-540.

Nybom, T. (2008). University autonomy: a matter of political rhetoric? In: L. Engwall \& D. Weaire (eds.), The University in the Market. Wenner-Gren International Series, 84. Stockholm.

OECD (2012). A Guiding Framework for Entrepreneurial Universities. Available at: https://www.oecd.org/site/cfecpr/EC-

OECD\%20Entrepreneurial\%20Universities\%20Framework.pdf (accessed 26 June 2017).

Perkmann, M., Tartari, V., McKelvet, M., Autio, E., Broström, A., D’Este, P., ,Fini, R., Geuna, A., Grimaldi, R., Highes, A., Krabel, S., Kitson, M., Llerena, P., Lissoni, F., Salter, A. \& Sobrero, M. (2013). Academic engagement and commercialisation: A review of the literature on university industry relations. Research Policy, 42, 423-442.

Perren, L. \& Jennings, P.L. (2005). Government discourses on entrepreneurship: issues of legitimization, subjugation, and power. Entrepreneurship Theory and Practice, 29 (2), 173-184. 
Philpott, K., Dooley, L., O’Reilly, C., Lupton, G. (2011). The entrepreneurial university: Examining underlying academic tensions. Technovation, 31, 161-170.

Potter, J. (1996). Representing Reality. Discourse, Rhetoric and Social Construction. London: Sage.

Potter, J. \& Wetherell, M. (1987). Discourse and social psychology. Beyond attitudes and behaviour. London: Sage.

Redford, D.T. \& Fayolle, A. (2014). Stakeholder management and the entrepreneurial university. In: A. Fayolle \& D.T. Redford (eds.), Handbook on the Entrepreneurial University. Cheltenham: Edward Elgar.

Reynolds, J., Wetherell, M. \& Taylor, S. (2007). Choice and chance: negotiating agency in narratives of singleness. The Sociological Review, 55 (2), 331-351.

Rinne, R. (2019). Suomalaisen yliopiston tila: Rahan, vallankäytön ja hallinnan uudet muodot. In H. Nori, H. Laalo \& R. Rinne (eds.), Kohti oppimisyhteiskuntaa - Koulutuspolitiikan uusi suunta ja korkeakoulutuksen muuttuva maisema (pp. 451-486). Turun yliopiston kasvatustieteiden tiedekunnan julkaisuja A:217. Turun yliopisto.

Ross, S.A. (1973).The Economic Theory of Agency: The Principal's Problem. The American Economic Review, 63 (2), 134-139.

Shapiro, S. (2005). Agency Theory. Annual review of sociology, 31, 263-284.

Shore, C. \& McLauchlan, L. (2012). “Third mission” activities, commercialization and academic entrepreneurs. Social Anthropology, 20 (3), 267-286.

Siegel, D.S. \& Wright, M. (2015). Academic entrepreneurship: Time for a Rethink? British Journal of Management, 26, 582-595. 
Siitonen, J. (2016). ’Synnytetään semmonen pöhinäpaikka”. Unpublished master's thesis, University of Helsinki, Finland.

Sørensen, B.M. (2008). 'Behold, I am making all things new': The entrepreneur as savior in the age of creativity. Scandinavian Journal of Management, 24, 85-93.

Ylijoki, O. H. (2003). Entangled in academic capitalism? A case-study on changing ideas and practices of university research. Higher Education, 45, 307-335. 